University of Nebraska - Lincoln

DigitalCommons@University of Nebraska - Lincoln

US Army Research

U.S. Department of Defense

2012

Clinical Auscultation In Noisy Environments

Steven Gaydos

U.S. Army Aeromedical Research Laboratory

Follow this and additional works at: https://digitalcommons.unl.edu/usarmyresearch

Gaydos, Steven, "Clinical Auscultation In Noisy Environments" (2012). US Army Research. 195.

https://digitalcommons.unl.edu/usarmyresearch/195

This Article is brought to you for free and open access by the U.S. Department of Defense at DigitalCommons@University of Nebraska - Lincoln. It has been accepted for inclusion in US Army Research by an authorized administrator of DigitalCommons@University of Nebraska - Lincoln. 


\section{$\square$ CLINICAL AUSCULTATION IN NOISY ENVIRONMENTS ${ }^{1,2}$}

\section{To The Editor:}

I was impressed with the recent article, "In-flight Thoracic Ultrasound Detection of Pneumothorax in Combat," by Dr. Justin Madill (1). It gives us all great pride to know of the life-saving and life-sustaining work that our nation's military Emergency Physicians do every day in austere conditions in deployed environments!

The author is, indeed, correct to note that medical evacuation (and casualty evacuation-medical evacuation in airborne or ground vehicles without intrinsic, dedicated patient care modalities) is very different from operating among the environs of the Emergency Department (ED). Hypobaria, hypoxia, hypothermia, vibration, noise, confined spaces, limited patient access, and other physical and physiologic stressors of flight contribute to these challenges (2).

I was particularly cued on the comment noting that "auscultation of breath sounds while in-flight would be futile due to the high ambient noise of the helicopter." In fact, this is not a problem solely for the militaryphysicians are often required to evaluate, make clinical decisions, and initiate treatment under noisy conditions. Auscultation is a fundamental and powerful clinical tool-it is rapid, simple, inexpensive, portable, and repeatable. But meaningful auscultation is challenging at best, often impossible, in high-noise environments. This might include being in the back of an aircraft or vehicle, in a very noisy $\mathrm{ED}$, or even at the point of injury in a noisy environment (e.g., a stadium). The U.S. Army Aeromedical Research Laboratory (USAARL), located at Fort Rucker, AL, has been addressing this challenge.

\footnotetext{
${ }^{1}$ The author has no financial or other relationships that may be perceived as a conflict of interest to report.

${ }^{2}$ Disclosure statements: The views, opinions, and findings contained in this document are those of the author and should not be construed as an official Department of the Army position, policy, or decision, unless so designated by other official documentation.
}

Recognizing the need for a device capable of adequate preservation of signal-to-noise ratio (SNR) under conditions of noise, USAARL partnered with Active Signal Technologies, Inc. (Linthicum Heights, MD), through a Small Business Innovative Research collaboration, to develop a "noise-immune stethoscope" (NIS) $(3,4)$. The NIS is a hybrid dual-mode design stethoscope with both an acoustic (passive) and a Doppler (active) mode. It is designed for one-handed operation and is powered by two AA-cell batteries. The acoustic mode consists of a directly coupled piezoelectric ceramic stack, whereas the Doppler operates with a $2-3-\mathrm{MHz}$ ultrasound carrier wave.

Most recent testing in a reverberation acoustic chamber demonstrated that the device preserves SNR and provides a clinically useful signal (heart and lung sounds) to approximately $90 \mathrm{~dB}$ of ambient noise for the acoustic mode (a good solution for many moderate noise environments), whereas the Doppler functioned out to $110 \mathrm{~dB}$ (testing limit; cabin noise in a UH-60 Blackhawk helicopter) (5). In-flight tests in an Army UH-60 helicopter also confirmed the ability to auscultate normal heart and lung sounds using the Doppler mode (6). It is worth noting that the audible returns of the Doppler mode are distinctly different than a traditional stethoscope. Heart sounds have been described as a three-part "ta-dá-da" rhythm, and lung sounds are comparable to a coarse friction rub. Presumably, clinicians can be trained to recognize and interpret these sounds. What is unknown at this time (studies are underway) is the diagnostic potential of the device under conditions of pathology.

With his new invention, the stethoscope, in 1816, Rene Laennec noted that the sounds of intrathoracic organs can prove useful for clinical assessment and diagnosis (7). This has, indeed, proved true. But, emergency physicians and other clinical providers often operate in austere, challenging environments that compromise the usefulness of the stethoscope. Ambient noise, particularly within and around medical evacuation vehicles, is certainly one of those challenges. Although high-noise environments are currently an impediment to clinical auscultation, this may not always be so. Research in improved electronic and Doppler stethoscopes is underway, and soon the clinician may be able to use a stethoscope with ease under the noisiest of conditions to assess, diagnose, and direct life-saving care. 
Steven Gaydos, MD, MPH

Warfighter Performance and Health Division U.S. Army Aeromedical Research Laboratory

Fort Rucker, Alabama

doi:10.1016/j.jemermed.2011.07.039

\section{REFERENCES}

1. Madill JJ. In-flight thoracic ultrasound detection of pneumothorax in combat. J Emerg Med 2010;39:194-7.

2. Davis JR, Johnson R, Stepanek J, Fogarty JA. Fundamentals of aerospace medicine. $4^{\text {th }}$ edn. Philadelphia, PA: Lippincott, Williams, \& Wilkins; 2008.
3. Houtsma AJ, Curry IP, Sewell JM, Bernhard WN. A dual-mode noise-immune stethoscope for use in noisy vehicles. Army Science Conference, Orlando, FL, 2006.

4. Houtsma AJ, Curry IP, Sewell JM, Bernhard WN. Dual-mode auscultation in high-noise level environments. Aviat Space Environ Med 2006;77:294-5.

5. Gaydos SJ, Williams RA, Reeves ER, Kelley AM. USAARL Technical Report 2010-12: Preliminary characterization of the noise-immune stethoscope in high ambient noise environment using a reverberation sound chamber. Fort Rucker, AL: U.S. Army Aeromedical Research Laboratory; 2010.

6. Houtsma AJ, Curry IP. USAARL Technical Memorandum 2007-14: Auscultation with a noise-immune stethoscope during flight in a Blackhawk helicopter. Fort Rucker, AL: U.S. Army Aeromedical Research Laboratory; 2007.

7. Bloch H. The inventor of the stethoscope: Rene Laennec. J Fam Pract 1993;37:191. 